\title{
A Comparative Study on the Financial Performance before and After the Implementation of Corporate Social Responsibility at the Company "Al madar Telecommunication Company as a Case Study"
}

\author{
Moutaz Abdelhamied Ali Kablan \\ Accounting Division, Faculty of Economics, University of Benghazi, Benghazi, Libya
}

Received date: 12 Avril 2017; Accepted date: 21 Avril 2017; Published date: 25 May 2017

Academic Editor: Motilewa Bolanle Deborah

Copyright (C) 2017. Moutaz Abdelhamied Ali Kablan . Distributed under Creative Commons CC-BY 4.0

\begin{abstract}
This study aimed to identify the impact of the implementation of the corporate social responsibility "CSR" with its four dimensions as economical, legal, ethical, and discretional on the company's financial performance, by two common financial indicators : return on assets "ROA" and return on sales "ROS". Memorable, Almadar telecommunication company has been chosen as a case study because it is a unique one in the Libyan business filed which incurs the social responsibility activities by managerial structure and professional treatments. Consequently, relying on the data collection by multi tolls "questionnaire, interviews, and analysis of financial statements", additionally, testing the four sub-hypotheses by Pearson correlation test, the study became able to present satisfied and scientific evidence to recognize that, there is a significant relationship between the implementation of "CSR" and the enhancement of Almadar financial performance over all the four dimensions of "CSR", stated earlier.
\end{abstract}

Keywords: corporate social responsibility- firm performance - telecommunication company.

Cite this Article as: Moutaz Abdelhamied Ali Kablan (2017), "A Comparative Study on the Financial Performance before and After the Implementation of Corporate Social Responsibility at the Company "Al madar Telecommunication Company as a Case Study", Journal of Accounting and Auditing: Research \& Practice, Vol. 2017 (2017), Article ID 993686, DOI: $10.5171 / 2017.993686$ 


\section{Introduction}

First and foremost, the firm cannot be active without interaction with its environment, so the isolation is not possible even if it has been selected by the firm.

This assurance let the top management of the organization take in its concern crossing its vision and enduring the social tasks toward these employees or the rest of the population alike.

The recent business mentality has changed from the accepted economical firm to the accepted social firm, which trend has been required by multi pioneer global organizations like "UN,_1994" or huge numbers of discretionary societies and syndicates.

There are multi scientific pieces of evidence suggesting that "CSR" actions lead the firm to gaining satisfaction of employees, customers, citizens, and the government as all, which step that maximizes the value of the firm within the progressive demand of the customers about the goods or services and the advantages by the authorities- like free taxation and banking priorities ( Mellahi , 2011).

In addition, the firms are increasingly facing the pressure from other groups of stakeholders to become environmentally responsible, Investors for instance are demanding companies to become more socially responsible. Thus, corporate leaders may find themselves obligated to adopt "CSR"- in order to attract their various "CSR" friendly stakeholders (Beret , 2011).

\section{CSR Background and Definition}

The persuasion of corporate social responsibility "CSR" has been debated about five decades before, it was referred to more often as social responsibility "SR" than as "CSR" (Caroll , 1999).

So, Bowen contributions have stated an initial definition of social responsibility in (1953) as "it refers to the obligations of business to pursue those policies, to make those decisions, or to follow those lines of actions which are describe in terms of the objectives and values of our society" (Inoue and Seoki , 2011 : 794).

At the same way, there are multi researchers who define "CSR" as "an organization's obligation to maximize its positive impact on stakeholders, and minimize its negative impact" (Brinkman and Peattie, 2008 : 25).

In fact, there are countless definitions to " CSR" by multi writers, But it is also critical that "CSR" should encompass organizational accountability concerning the environment, but the most hugely cited definition was presented by (Caroll,1997) stating that "the social responsibility of business encompasses the economical, legal, ethical, and discretional expectations that society has of organizations at any given point in time. He argued that these social responsibilities carried by the firm are for the sake of both the society at large and the firm itself. So firms are obligated to take the society's interest into consideration when taking decisions because finally the society is greatly affected by these decisions.

Otherwise, there are many opinions that have stated that all four dimensions which mentioned earlier will be reflected finally within the financial dimension. So if the management takes in its concern the social dimensions during all operations, the firm will realize multi positive financial indicators like increasing return on assets "ROA", and return on sales "ROS" of goods or services alike (Russo and Perrini, 2010 ).

This enhancement will be achieved throughout the progressive demand by customers and advantages which were presented by the authorities like the credit banking peculiarities and the taxation dispensations, and others.

On other hand, there are many efforts of policy makers and various stakeholders representatives to spread the idea of socially responsible behavior. For example, in "2001" the commission of the European communities defined "CSR" as "a concept whereby companies integrate social and environmental concerns their business operations on a voluntary basis". 
While the world bank "WB" defines "CSR" as "the commitment of business to contribute to sustainable economical development by working with employees, their families, the local community and society at large to improve their lives in ways that are good for business and for development" (Maloney , 2010).

According to my point of view, the satisfaction of the employees toward their firm throughout the social activities like the medical insurance, entertainment aspects and the rest of the social affairs will strongly help to upgrade their moral spirit, to give better and better in favor of their firm.

Moreover, some of the definitions of "CSR" in the $2000_{\text {s }}$ correspond to "CSR" as a concept whereby companies integrate social and environmental concerns in their business operations and interactions with the stakeholders, other definitions indicated that "CSR" is achieving commercial success in way that honors ethical values and respect people, social communities and the natural environment (Park , 2010).

Therefore, the scanning of Caroll's model in "1979" identified and adopted mainly four dimensions, namely the economical, the legal, the ethical, and the philanthropic or discretional ones. In "1991" Caroll revisited this four parts definition of "CSR" and regulated the concept of multiple corporate social responsibilities. And due to the opinion based on that all the four dimensions by Caroll will appeared by the financial dimension within the long-term during the multi indicators like "ROA" and "ROS". So the author became able to state the following model, diagramed in figure "1"

CSR " $X_{1} X_{2} X_{3} X_{4} "$

Financial performance "Y"

Four dimensions

Two indicators alike

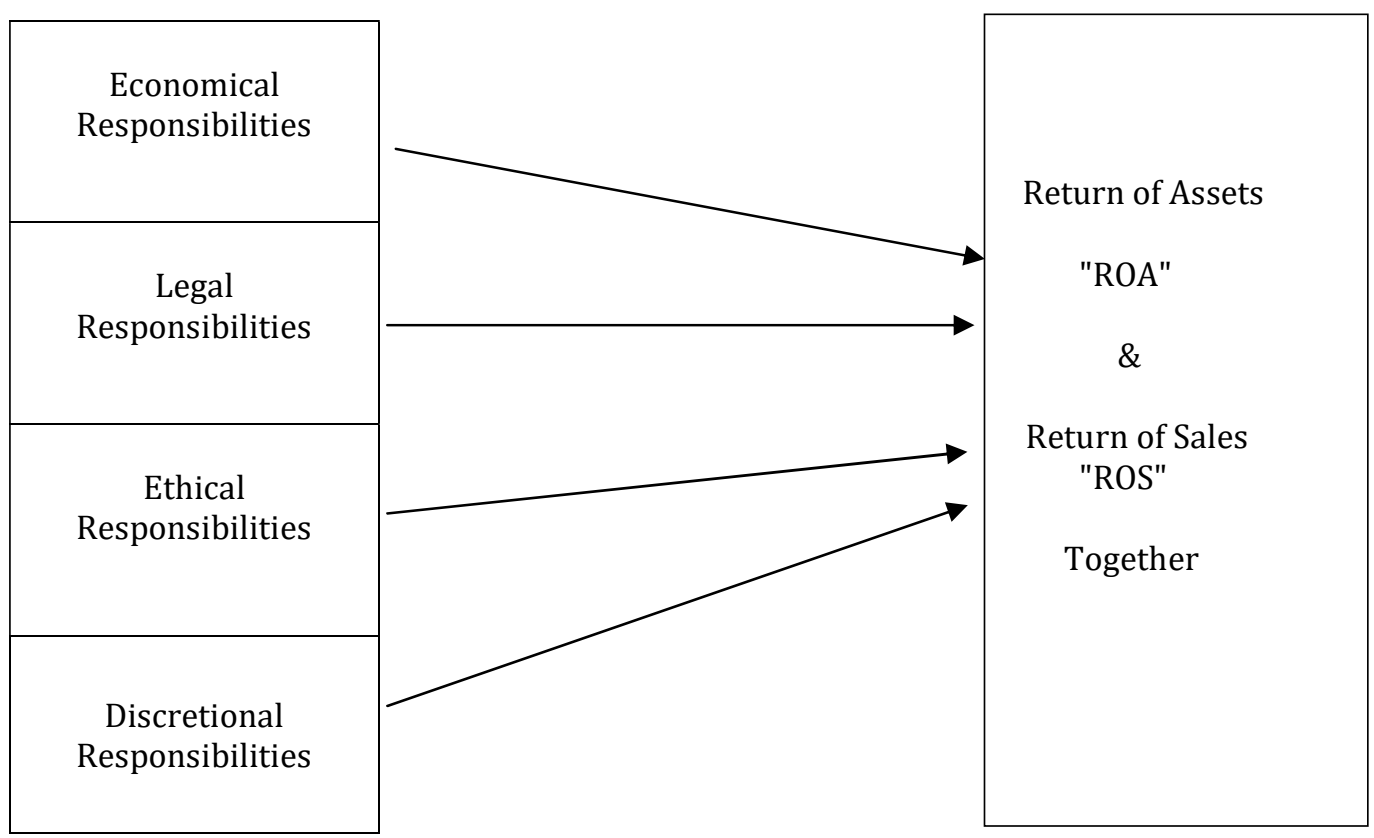

Figure "1" The model of study

Then, the independent variables of the study are: the economical responsibilities, the legal responsibilities, the ethical responsibilities, and the discretional responsibilities. On the other side, the dependent variable is the firm 
performance, which will be measured by "ROA" and " ROA" alike.

\section{Literature Review and Hypotheses Development}

Within the last two decades corporate social responsibility had gained momentum worldwide. Multi researchers and academics are interested in identifying who gains the benefits from, and who bears the costs of.

In addition, past research on corporate social performance has mainly attempted to determine whether the social involvement of business is associated with positive or negative levels of financial performance and profitability ( Kempf and Oslhoff , 2007 ; Jackson and Parse , 2009).

However, the results of many empirical studies of the relationship between "CSR" and profitability have been inconclusive, reporting, positive, negative, and neutral results. For example, (Pava and Krausz , 1996) have examined "21" studies of corporate social performance and financial performance between "1972" and "1992". The findings of the "12" studies demonstrated a positive association, eight of total showed no association, and only one study indicated a negative correlation.

On the other hand, (Stanwick, 1998) has examined the relationship between corporate social performance and the financial performance of an organization between "1987" to "1992". The results of this study show a significant positive correlation between the corporate social performance and profitability for all six years of the study. This study supports the view that the profitability of a firm allows and encourages managers to implement programs that increase the level of corporate social responsibility.

In the same direction, (Baron and Norman, 2007) measured the firm's financial performance "profitability" by using two accounting variables - return on assets and return on sales, providing a range of measures used to assess corporate financial performance by the investment community. They found that firms that have financial troubles may have little ability to make discretionary investment in traditional "CSR" activities such as philanthropy, while those doing finance have resources to spend in ways that may have more long-term strategic impacts, such as investments in improving local schools or community conditions to enhance the workforce. Additionally, the results indicated that there is a positive link between "CSR" and financial performance.

(Lou and Battachrya, 2008) found that corporate social responsibility contributes positively to market value and financial performance. In addition, "CSR" influences the firm's performance throughout the customers satisfaction.

The couple suggested that the managers can obtain competitive advantages and reap more financial benefits by investing corporate social responsibility. At the same way, they mentioned that "CSR" practices can and often do impact financial performance negatively in the shortterm, and they cannot replace simply product contributes, a poor product sold by a highly ethical firm will not gender loyalty levels needed to drive financial performance (Inoue and Seoki , 2011).

(Bird and et all , 2012) also found a positive relationship to exist between an aggregate score for "CSR" activates and corporate performance, but concluded that this finding did not extend to the relationship between each individual "CSR" activity and the corporate performance.

Consequently, based upon the scanning of the related accounting literature, the study became able to state the main hypothesis, as followed:

\section{"There is- a significant relationship between the implementation of "CSR" in the Libyan companies, specifically in Almadar telecommunication company and its financial performance."}

Due to, the "CSR" contents of four dimensions as stated earlier, the study was based upon two indicators to measure the financial performance of firm- return on assets "ROA" and return on sales "ROS", then, to examine the main hypotheses, the author branched four subhypotheses, as followed: 
The first sub-hypothesis: there is a significant relationship between the economical dimension and "ROA","ROS" alike.

The second sub-hypothesis: there is a significant relationship between the legal dimension and "ROA","ROS" alike.

The third sub-hypothesis: there is a significant relationship between the ethical dimension and "ROA","ROS" alike.

The fourth sub-hypothesis: there is a significant relationship between the discretional dimension and "ROA","ROS" alike.

\section{Aim of the study}

This study aims to identify the impact of corporate social responsibility in the Libyan companies on their financial performance throughout two indicators "ROA" and "ROS" alike, specifically in Almadar Telecommunication Company.

\section{The Study Importance}

Due to the survey of the Libyan varietal studies, this study is classified as a one of the headmost ones which examined the impact of "CSR" on the firms performance. Moreover, this study contributes by empirical evidence to present the dimensions of the "CSR" by multi interviews, which have been done by the author with the supreme employees of Almadar Telecommunication Company

\section{The Methodology of the Study}

The methodology presents all the steps during the study trail either theoretical or practical aspects alike, so this section contents of the following sub-contents:

\section{The method of the study}

This study is based upon the induction approach, whereas reviewed the related previous studies, then stated their hypotheses. Accordingly, the deduction approach has relied examining these hypotheses, then presenting the findings and conclusion.

\section{The study design and data collection}

Throughout this section of study the following components will be mentioned : the justification of choosing Almadar telecommunication company as a case study -compendium of Almadar "CSR" - presenting of the data collection tools.

\section{The justification of choosing Almadar company as a case study}

Relying on the pilot study, done by the author, there is no Libyan company which aware of the utility of the social responsibility for the population and the firm alike as our case "Almadar company". Moreover, it is the unique firm in the Libyan business environment that has a general department and related divisions for the social responsibility affairs throughout its managerial structure.

In addition, Almadar company is the solitary firm which early absorbed the United Nations "UN" philosophy that goes by "the firm that gains profits by the community must endure social and environmental expenses as a partial quota of these profits for ethical assurances".

\section{Compendium of Almadar "CSR"}

Basically, Almadar company had started enduring the social responsibility expenses during the beginnings of "2008", but these efforts are still for multi years without organized polices and specific procedures, so this randomly expenses still need for long time, to be recognized, measured, and disclosed accurately according to accepted accounting basis.

During "2008", an independent general department for social responsibility affairs had been founded with related divisions, one in the supreme management location in Tripoli, and the other in the eastern department branch in Benghazi.

So, all of these divisions consists of three offices:

$\checkmark$ First one: the social responsibility expenses unit.

$\checkmark$ Second one: the media affairs and general relationships unit. 
Third one: the managerial communication and activity unit.

Besides, the financial statements of Almadar company had become disclosed all the social activities expenses in the income statement, and the assets which related to these social activities in its balance statement about "2008" and over. Memorable, multi interviews have been done by the author as followed:

$\checkmark$ A member of board of directors, on "5 / 1 / 2017".

$\checkmark$ Chairman of the general department of social responsibility affairs in supreme management, in Tripoli, on "11 / 1 / 2017".

$\checkmark$ Chairman of the department of financial affairs, in the eastern area branch, in Benghazi, on "18 / 1 / 2017".

$\checkmark$ Chairman of social responsibility division in supreme management, in Tripoli, on "25 / 1 / 2017".

$\checkmark$ Chairman of social responsibility division in the eastern area branch, in Benghazi, on "25 / 1 / 2017".

$\checkmark \quad$ Chairman of social responsibility expenses in the eastern area branch, on "29 / 1 / 2017".

$\checkmark$ Chairman of the media affairs and general relationships unit in the eastern department branch, on "29 / 1 / 2017".

$\checkmark$ Chairman of the managerial communication and activity unit in the eastern area branch, on "30 / 1 / 2017".

According to these interviews, the study can present all aspects of "CSR" in Almadar company, like the following:

$\checkmark$ The first aspect is the social contribution, it treated in fact the following activities about the last decade, for example:

- Maintenance of about over "400" mosques around Libya.

- Concreting the building of passports, nationalities, and immigration of Benghazi.

- Maintenance of the tower of Benghazi airport.

- Providing some medical equipments for Tripoli medical center and Benghazi medical center alike.

- Maintenance of Tripoli airport.
- Maintenance of Elabrag airport in Baydah.

$\checkmark \quad$ The second aspect is the social care. This section of "CSR" is been decided by the general manager of the company, and the manager of the eastern department branch, everyone in his location, with an amount of "100,000" Libyan dinars per every one annually, as free.

The third aspect is the solidarity fund. By the way, this section is specific for the social events and crises of the employees of the firm. So this aspect covers the following liabilities:

- The medical insurance "except the cosmetic dental treatment" for the employee and his close family, in addition to the parents.

- Death of the employee with an amount that equals "3000" Libyan dinars.

- Death of one of the employee's close family or one of his parents, with an amount equal "1500" Libyan dinars.

- Every new born childe, with an amount that equals '"500" Libyan dinars.

- The first wedding day, with an amount equaling "2000" Libyan dinars.

- The hajj relief, with an amount equaling "1500" Libyan dinars, for once.

Notable, what is stated before about the activities of the "CSR" in Almadar company are just for examples, so multi activities are been done by the firm toward the employees and the rest of the society.

\section{Data collection tools}

Due to the fact that, this study is based on the case study philosophy, so we need more than one tool to achieve the objective of the study. Basically, the study relied on interviews to identify the indicators of the four dimensions of the "CSR" to examine the four sub-hypotheses of the study.

Therefore, the interview mentioned earlier with vital positions of Almadar company presented the indicators of the four dimensions, which guaranteed within the other data collection tool "the questionnaire". 
The questionnaire of the study has been issued with four sections, every section consists of multi indicators that about every dimension, which examine hypotheses of the- the sub four ones?.
The author has taken in his concern then framing the questionnaire, that the sentences were based on the recognition - non of the significant relationship between every phrase and "ROA","ROS" alike, with five degrees of acceptance or refusal like the following:

Table "1" The Questionnaire of the Study

\begin{tabular}{|c|c|c|c|c|c|c|}
\hline \multirow[b]{2}{*}{ Dimension } & \multirow[b]{2}{*}{ Indicator } & \multicolumn{5}{|c|}{ Degree of response } \\
\hline & & $\begin{array}{c}\text { Highly } \\
\text { accepted }\end{array}$ & Accept & Neutral & Refuse & $\begin{array}{l}\text { Highly } \\
\text { refused }\end{array}$ \\
\hline Economical & $\begin{array}{l}\text { 1) Responses of customer complaints. } \\
\text { 2) Quality of products. } \\
\text { 3) Customers satisfaction } \\
\text { 4) Minimizing the operating costs. } \\
\text { 5) Monitoring employee productivity. } \\
\text { 6) Engaging in long-term business } \\
\text { strategy. }\end{array}$ & & & & & \\
\hline Legal & $\begin{array}{l}\text { 1) Environmental laws } \\
\text { 2) Legal standards } \\
\text { 3) Compliance with law } \\
\text { 4) Hiring laws regulation. } \\
\text { 5) Diversity of workforce. } \\
\text { 6) Avoiding the discrimination. } \\
\text { 7) Following internal policies of } \\
\text { recommendation among employees. }\end{array}$ & & & & & \\
\hline Ethical & $\begin{array}{l}\text { 1) Code of conduct. } \\
\text { 2) professional standards. } \\
\text { 3) Monitoring of activity. } \\
\text { 4) Trustful company. } \\
\text { 5) Fairness employees evolution } \\
\text { 6) Providing full and accurate } \\
\text { information to customers. }\end{array}$ & & & & & \\
\hline Discretional & $\begin{array}{l}\text { 1) Competitive salary. } \\
\text { 2) support for education and job train- } \\
\text { ing programs. } \\
\text { 3) Encouraging employees to join phila- } \\
\text { nthropic organizations. } \\
\text { 4) Energy and materials program of } \\
\text { reduction support for local community. } \\
\text { 5) Direct involvement in community } \\
\text { projects and affairs. } \\
\text { 6) An employee-led approach of phil- } \\
\text { anthropy. } \\
\text { 7)Offering generous product warranties. } \\
\text { 8) Campaigning for environmental and } \\
\text { social changes. }\end{array}$ & & & & & \\
\hline
\end{tabular}




\section{Analysis and findings}

Due to the fact that, the study relied on interviews firstly, questionnaires secondly as the tools of data collection of study, the study's hypotheses have been tested by using the collected data from the survey of all levels of
Almadar company management, which related to and oriented "CSR".

In fact, about "92" questionnaire have been distributed about the sample of Almadar company, so the details of the received ones are shown within the following table:

Table "2" Details of the Questionnaire Distribution

\begin{tabular}{|l|c|c|}
\hline \multicolumn{1}{|c|}{ The targeted position"s" } & Sent & Received \\
\hline 1) Board of directors. & 3 & 1 \\
2) General manager of the company. & 1 & 1 \\
3) General manager of the eastern area branch. & 1 & 1 \\
4) Chairman of the general department of social responsibility affairs. & 1 & 1 \\
5) Chairman of "CSR" division in supreme management, and his total team. & 18 & 16 \\
6) Chairman of "CSR" division in the eastern are branch, and his total team. & 10 & 8 \\
7) Chairman of general department of financial affairs in supreme management, \\
and his team. \\
8) Chairman of the department of financial affairs of the eastern area branch, and \\
his team. \\
9) Chairman of the general department of internal auditing in supreme \\
management. \\
10) Chairman of internal auditing division in supreme management, and his team. \\
$\begin{array}{l}\text { 11) Chairman of internal auditing division in the eastern branch, and his team. } \\
\text { Total }\end{array}$ \\
\hline
\end{tabular}

\section{Descriptive statistics}

Table "3" illustrates the minimum and maximum values for the variables. The descriptive findings show the central tendency and dispersion of the indicators.
The calculated mean of corporate social responsibility "CSR" equals "4.141", the standard deviations as a measure of dispersion "0.53". The calculated means of the four dimensions of the "CSR" are "4.230" for economical dimension, "4.216" for legal dimension, "4.353" for ethical dimension, and "3,762" for discretional dimension. The 
standard deviations are "0.72" for economical dimension. "0.62" for legal dimension, " 0.61 " for ethical dimension, and "0.55" for discretional dimension.
The calculated mean of the financial performance "ROA" as a measure of profitability is "3.41", and the "ROS" is "3.59". The standard deviations as a measure of dispersion are "0.80" for "ROA", and "0.74" for "ROS".

Table "3" Descriptive Statistics

\begin{tabular}{|l|c|c|c|c|c|}
\hline \multicolumn{1}{|c|}{ Variables } & Mean & S.D & Min & Max & Observations \\
\hline Perfo 1 "ROA" & 3,4100 & 0.8000 & 1,0000 & 5.0000 & 73 \\
Perfo 2 "ROS" & 3.5900 & 0.7400 & 2.0000 & 5.0000 & 73 \\
"CSR" & 4.1410 & 0.5269 & 2.2700 & 4.9500 & 73 \\
Economical - dime & 4.2304 & 0.7239 & 1.0000 & 5.0000 & 73 \\
Legal - dime & 4.2164 & 0.6204 & 2.0000 & 5.0000 & 73 \\
Ethical - dime & 4.3530 & 0.6078 & 2.1700 & 5.0000 & 73 \\
Discretional- dime & 3.7620 & 0.5499 & 2,2000 & 4.9000 & 73 \\
\hline
\end{tabular}

\section{Reliability test}

The cronbach Alpha coefficient was used to assess reliability - Alpha has been proposed as the most appropriate means assessing reliability in management accounting researchers. In this an Alpha coefficient of around "0.83", was adopted. All scales were found to satisfy this reliability criterion with Cronbach Alpha coefficients for economical dimension = "0.93", for legal dimension= "0.93", for ethical dimension $=$ "0.93", and for discretional dimension $=$ "0.92".

\section{Hypotheses testing}

As stated earlier, this study tests four subhypotheses, correlation analysis was used to test these hypotheses .

Indeed, multiple regressions were used to test the four hypotheses.

The main hypothesis concerned the relationship between "CSR" and the firm performance, as the following:

"There is a significant relationship between the implementation of "CSR" in the Libyan companies, specifically in Almadar telecommunication company and its financial performance."
In other word, the author can state this main hypothesis as "there is a significant relationship between the four dimensions of the "CSR" and Almadar financial performance."

Pearson correlation coefficients for all variables are presented in table "4". Table "4" indicates that a positive correlation was evident between Almadar firm performance "ROA" and "CSR" "R $=0,300 "$ at "1\%" level.

Also "ROA" has a positive correlation with the four dimensions of "CSR", where economic "R = $0,236 "$, legal " $\mathrm{R}=0.229$ " at " $5 \%$ " level, whereas ethical " $\mathrm{R}=0.275$ ", and discretional " $\mathrm{R}=0.273$ " at "5\%" level.

On the other side, "ROS" as the second firm performance at our study, Pearson correlation of "ROS" and all variables are been presented in table "4". Table "4" indicates that a positive correlation was evident between Almadar firm performance "ROS" and "CSR" " $r=0.362$ " at "1\%" level.

Also "ROS" has positive correlation with the four dimensions of "CSR", where economical dimension " $r=0.299 "$, the ethical " $r=0.301 "$, the ethical " $r=0.284 "$, and the discretional $" r=$ 0.334 " at "1\%" level. 
Table "4" Correlation Matrix

\begin{tabular}{|c|c|c|c|c|c|c|c|}
\hline Indicator & $X_{1}$ & $X_{2}$ & $\mathbf{X}_{3}$ & $X_{4}$ & $X_{5}$ & $X_{6}$ & $X_{7}$ \\
\hline $\begin{array}{l}\text { "CSR" "X" } \\
\text { Perfo - "ROA" "X" } \\
\text { Perfo - "ROS" "X } \\
\text { Economical - dime "X" } \\
\text { Legal - dime" } \mathrm{X}_{5} " \\
\text { Ethical - dime" } \mathrm{X}_{6} " \\
\text { Discretional- dime" }\end{array}$ & $\begin{array}{l}1.000 \\
0.300^{* *} \\
0.362^{* *} \\
0.833^{* *} \\
0.901^{* *} \\
0.818^{* *} \\
0.801^{* *}\end{array}$ & $\begin{array}{l}1.000 \\
0.856^{* *} \\
0.236^{*} \\
0.229^{*} \\
0.275^{* *} \\
0.273^{* *}\end{array}$ & $\begin{array}{l}1.000 \\
0.299^{* *} \\
0.301^{* *} \\
0.284^{* *} \\
0.334^{* *}\end{array}$ & $\begin{array}{l}1.000 \\
0709^{* *} \\
0.501^{* *} \\
0.505^{* *}\end{array}$ & $\begin{array}{l}1.000 \\
0.664^{* *} \\
0.642^{* *}\end{array}$ & $\begin{array}{l}1.000 \\
0.608^{* *}\end{array}$ & 1.000 \\
\hline
\end{tabular}

*statistically significant at the "5\%" level

*statistically significant at the "1\%" level

The findings of this study found that there is a significant and direct relationship between all four dimensions of the "CSR" and the enhancement of the financial performance by its two indicators "ROA", "ROS" alike. Then the author accepted all four sub-hypotheses of study stated earlier.

Consequently, based on our statistical analysis outputs, the study becomes able to accept its main hypothesis, which is

"there is a significant relationship between the four dimensions of "CSR" and Almadar financial performance."

\section{Conclusion}

This study investigated the relationship between the implementation of "CSR" of Almadar telecommunication company as a case study of the Libyan companies and its financial performance by two indicators: "ROA" and "ROS".

The findings of this study found that there is a positive and significant impact of "CSR" by the four dimensions: economical, legal, ethical, and discretional on Almadar financial performance.
Most recent studies found that corporate social responsibility contributes positively to enhancing the financial performance of firms, additionally, that the firm performance has been influence by "CSR" through customer satisfaction or market orientation.

This means that "CSR" is used as a mediator or moderator in relation to the firm performance while this is not found in this study where it is affect the firm performance directly.

\section{References}

Baron, M ; Norman, A (2007), Consumer Response to Retailer Use of Cause-Related Marketing : Is More Fit Better?, Journal of Retailing, 83(1), 437- 445.

Berete, M (2011), Relationship Between Corporate Social Responsibility and Financial Performance in the Pharmaceutical Industry, Unpublished Ph.D Dissertation, Walden University.

Bird, R ; Hall, A ; Momente, F ; Reggiani, F (2012), What Corporate Social Responsibility Activities are Valued by the Market?, Journal of Business Ethics, 76(2), 189 - 206.

Brinkmann, J ; Peattie, K (2008), Consumer Ethics Research : Reframing the Debate About 
Consumption for Good, Journal of Business Ethics and Organization Studies, 13(1), 22 - 30.

Carrol, A (1997), A Three - Dimensional Conceptual Model of Corporate Performance, The Academy of Management Review, 4(4), 497 $-505$.

Carrol, A (1999), Corporate Social Responsibility : Evolution of A Definition Construct, Business Society, 37, 268 - 294.

Inoue, Y; Lee, S (2011) Effects of Different Dimensions of Corporate Social Responsibility on Corporate Financial Performance in Tourism - Related Industries, Tourism Management, 32, $790-804$.

Jackson, L ; Parsa, H (2009), Corporate Social Responsibility and Financial Performance : A Typology for Service Industries, International Journal of Business Insights and Transformation, 2, $13-21$.

Kempf, A ; Osthoff, P (2007) The Effect of Socially Responsible Investing on Portfolio Performance, European Financial Management, 31(5), $908-922$.

Lou, X ; Bhattachanya, C (2008) Corporate Social Responsibility, Customer Satisfaction, and Market Value, Journal of Marketing, 70(4),pp 118.
Maloney, C (2010) Corporate Social Responsibility the New Strategic Marketing Battleground, Smash Words Edition.

Mellahi, K (2011) Market Orientation, Corporate Social Responsibility and Business Performance, Journal of Business Ethics, 99, 307 - 324.

Park, J (2010) Exploring the Effect of Corporate Social Responsibility on Firm Performance : Antecedent Mediators and Moderators, Unpublished Ph.D Dissertation.

Para, M ; Krausz, J (1996) The Association Between Corporate Social Responsibility and Financial Performance : The Paradox of Social Cost, Journal of Business Ethics, 15(3), pp" 321 327".

Russo, A ; Perrini, F (2010) Investigating Stakeholder Theory and Social Capital "CSR" in Large Firms and SMEs, Journal of Business Ethics, 17(6), 595 -612.

Stanwick, P ; Stanwick, S (1998) The Relationship Between Corporate Social Performance, and Organizational size, Financial Performance and Environmental Performance : An Empirical Examination, Journal of Business Ethics, 17, 195 - 204. 